\title{
Reversibility of the acute toxic effect of Cyclosporin A on pancreatic B cells of Wistar rats
}

\author{
H.-J. Hahn, A. Dunger, F. Laube, W. Besch, E. Radloff, C. Kauert and G. Kotzke \\ Central Institute for Diabetes "Gerhardt Katsch", Karlsburg, GDR
}

\begin{abstract}
Summary. This study investigated if and to what extent the acute toxic effect of Cyclosporin A on pancreatic Wistar rat $B$ cells is reversible. After 2 weeks of treatment rats developed marked glucose intolerance accompanied by reduced pancreatic insulin content due to a loss of $B$ cells, diminished islet DNA synthesis and decreased B-cell insulin content. Cyclosporin $\mathrm{A}$ had accumulated in the pancreas. Three weeks after withdrawal of Cyclosporin A, pancreatic tissue concentrations of Cyclosporin A were still 100 times larger than in serum. Glucose tolerance, however, had already improved, associated with an increase of B-cell insulin content and apparent islet replication, and the insulin response of isolated islets was reduced. Five weeks after the withdrawal of Cyclo-
\end{abstract}

sporin A, glucose tolerance was normal, but pancreatic insulin content and relative $\mathrm{B}$-cell volume were still diminished in comparison to vehicle-treated controls. Eight weeks after withdrawal, the morphometric parameters had also been normalized. The results suggest that the loss of pancreatic B cells is caused by a toxic destruction, possibly combined with an apparent decrease of replicatory activity. The acute toxic effects of Cyclosporin A in pancreatic B cells are stepwise reversible.

Key words: Cyclosporin A, pancreatic insulin content, glucose tolerance, islet insulin content, insulin secretion, B-cell volume, DNA-synthesis
Recently it has been demonstrated that Cyclosporin A, a powerful immunosuppressive drug successfully used in organ transplantation [1], exerts alterations on glucose metabolism [2, 3].

Detailed investigations revealed that therapeutically recommended doses of Cyclosporin A may lead to glucose intolerance [2,3], hyperglycaemia [2-4] and hypoinsulinaemia [2-4] accompanied by a marked decrease of pancreatic insulin content $[2,3]$. Further studies documented the involvement of two processes, a decrease of islet insulin content accompanied by a markedly decreased secretory response in vitro [2] and a toxic destruction of pancreatic B cells [4] leading to a diminution of B-cell volume [2]. This effect of Cyclosporin $A$ on pancreatic $B$ cells has implications for its potential use in Type 1 (insulin-dependent) diabetes, as repeatedly suggested [5-7], especially with respect to the restricted replicatory capacity of pancreatic B cells [8]. In this study we have investigated if and to what extent the acutely induced pancreatic B-cell alterations are reversible after withdrawal of Cyclosporin A in the Wistar rat.

\section{Materials and methods}

\section{Animals and experimental protocol}

Male Wistar rats (strain WOK, haplotype RT1 ${ }^{\text {u}}$ ) with a body weight of $160-180 \mathrm{~g}$ were used. Before and during treatment and after withdrawal of Cyclosporin A, body weight, plasma glucose, serum biliru- bin and creatinine, serum Cyclosporin $\mathrm{A}$ and glucose tolerance (intraperitoneal $2.0 \mathrm{~g}$ glucose $/ \mathrm{kg}$ body weight; determination of plasma glucose at $0,10,30,60$ and $120 \mathrm{~min}$ ) were repeatedly monitored in fed animals between 08.00 hours and 09.00 hours. The rats were either intramuscularly injected with $50 \mathrm{mg}$ Cyclosporin $\mathrm{A} / \mathrm{kg}$ body weight dissolved in $96 \%$ alcohol, which was diluted $1: 1(\mathrm{v} / \mathrm{v})$ with saline $(n=50)$ or with vehicle $(n=38)$ for 2 weeks. On the last day of treatment the glucose tolerance was measured. One day later the first group of animals (10 controls; 18 Cyclosporin A-treated) was anaesthetized, the abdominal cavity opened and venous blood collected. The pancreases were then prepared for determination of pancreatic insulin, glucagon and Cyclosporin content, for measurement of relative islet and relative B-cell volume and for isolation of pancreatic islets. The kidneys and liver were prepared for determination of Cyclosporin A tissue content. The remaining animals were surgically biopsied [9] to measure either pancreatic insulin content or relative Bcell volume to confirm the effect of Cyclosporin A treatment. Thereafter, the drug was withdrawn and 3 (12 controls, 12 treated), 5 ( 8 controls, 8 treated), 8 ( 8 controls, 12 treated) weeks later the same parameters were measured.

\section{Analytical methods}

Plasma glucose was measured using a Beckman glucose analyzer (Beckman Instruments, Fullerton, Calif, USA). Serum bilirubin and creatinine were determined using standard methods [10].

The pancreatic sample to be extracted was weighed, quickly frozen in liquid nitrogen and stored at $-25^{\circ} \mathrm{C}$ until acid extraction [11]. The extracts were diluted and used to measure insulin and glucagon concentration by radioimmunoassay $[12,13]$.

The parts of liver, kidney and pancreas used for determination of Cyclosporin A concentration were weighed, frozen in liquid nitrogen and stored at $-25{ }^{\circ} \mathrm{C}$ until acid-alcoholic extraction $[4,11]$. The $\mathrm{Cy}-$ closporin concentration of plasma and tissue was measured by a $\mathrm{Cy}-$ 
Table 1. Effect of Cyclosporin A on selected in vivo parameters.

\begin{tabular}{|c|c|c|c|c|c|c|c|c|c|c|}
\hline \multirow[t]{3}{*}{ Time } & \multicolumn{4}{|c|}{ Treatment period } & \multicolumn{6}{|c|}{ Post-treatment period } \\
\hline & \multicolumn{2}{|l|}{7 days } & \multicolumn{2}{|l|}{14 days } & \multicolumn{2}{|l|}{21 days } & \multicolumn{2}{|l|}{35 days } & \multicolumn{2}{|l|}{70 days } \\
\hline & Vehicle & Cyclosporin A & Vehicle & Cyclosporin A & Vehicle & Cyclosporin A & Vehicle $\mathrm{Cyc}$ & closporin A & Vehicle & Cyclosporin A \\
\hline $\begin{array}{l}\text { Body weight } \\
\text { gain }(\mathrm{g}) \\
\text { (compared } \\
\text { to day } 0 \text { ) }\end{array}$ & $\begin{array}{r}+28.5 \pm \\
1.3(21)\end{array}$ & $\begin{array}{l}+13.5 \pm \\
2.1^{\mathrm{a}}(21)\end{array}$ & $\begin{array}{r}+45.0 \pm \\
4.5(21)\end{array}$ & $\begin{array}{l}+2.5 \pm \\
2.6^{\mathrm{a}}(21)\end{array}$ & $\begin{array}{r}+61.5 \pm \\
2.7(12)\end{array}$ & $\begin{array}{r}+13.5 \pm \\
4.6^{\mathrm{a}}(12)\end{array}$ & $\underset{3.6(12)}{+128.5 \pm}+$ & $\begin{array}{l}-74.5 \pm \\
10.5^{\mathrm{a}}(12)\end{array}$ & $\begin{array}{r}+204.5 \pm \\
9.5(6)\end{array}$ & $\begin{array}{r}+156.0 \pm \\
11.0^{\mathrm{a}}(6)\end{array}$ \\
\hline $\begin{array}{l}\text { Body weight } \\
\text { gain }(\mathrm{g}) \\
\text { (compared } \\
\text { to day } 14 \text { ) }\end{array}$ & & & & & $\begin{array}{r}+16.5 \pm \\
3.1(12)\end{array}$ & $\begin{array}{r}+11.0 \pm \\
2.8(12)\end{array}$ & $\begin{array}{c}+83.5 \pm \\
4.1(12)\end{array}+$ & $\begin{array}{r}-72.0 \pm \\
6.8(12)\end{array}$ & $\begin{array}{r}+159.5 \pm \\
8.0(6)\end{array}$ & $\begin{array}{r}+153.5 \pm \\
7.0(6)\end{array}$ \\
\hline $\begin{array}{l}\text { Plasma glucose } \\
(\mathrm{mmol} / \mathrm{l})\end{array}$ & $\begin{array}{l}7.72 \pm \\
0.27(21)\end{array}$ & $\begin{array}{l}7.83 \pm \\
0.22(21)\end{array}$ & $\begin{array}{l}6.44 \pm \\
0.11(21)\end{array}$ & $\begin{array}{l}8.16 \pm \\
0.50(21)\end{array}$ & $\begin{array}{l}6.50 \pm \\
0.11(12)\end{array}$ & $\begin{array}{l}8.11 \pm \\
0.50^{\mathrm{a}}(12)\end{array}$ & $\begin{array}{l}4.16 \pm \\
0.16(12)\end{array}$ & $\begin{array}{l}6.22 \pm \\
0.50^{\mathrm{a}}(12)\end{array}$ & $\begin{array}{l}4.83 \pm \\
0.16(6)\end{array}$ & $\begin{array}{l}5.50 \pm \\
0.38(6)\end{array}$ \\
\hline $\begin{array}{l}\text { Bilinubin } \\
(\mu \mathrm{mol} / 1)\end{array}$ & $\begin{array}{l}10.0 \pm \\
1.6(12)\end{array}$ & $\begin{array}{l}9.7 \pm \\
0.8(12)\end{array}$ & $\begin{array}{l}7.1 \pm \\
0.6(12)\end{array}$ & $\begin{array}{l}11.3 \pm \\
0.9^{\mathrm{a}}(12)\end{array}$ & $\begin{array}{l}5.8 \pm \\
0.7(12)\end{array}$ & $\begin{array}{l}10.5 \pm \\
0.7^{2}(12)\end{array}$ & $\begin{array}{l}6.4 \pm \\
0.5(12)\end{array}$ & $\begin{array}{l}9.7 \pm \\
0.6^{\mathrm{a}}(12)\end{array}$ & $\begin{array}{l}7.4 \pm \\
0.8(6)\end{array}$ & $\begin{array}{l}10.2 \pm \\
1.4(6)\end{array}$ \\
\hline $\begin{array}{l}\text { Creatinine } \\
(\text { umol/1) }\end{array}$ & $\begin{array}{l}98.2 \pm \\
6.9(12)\end{array}$ & $\begin{array}{l}77.5 \pm \\
4.8(12)\end{array}$ & $\begin{array}{l}81.8 \pm \\
4.5(12)\end{array}$ & $\begin{array}{l}85.1 \pm \\
4.5(12)\end{array}$ & $\begin{array}{l}89.5 \pm \\
3.9(12)\end{array}$ & $\begin{array}{l}78.8 \pm \\
4.4(12)\end{array}$ & $\begin{array}{l}80.3 \pm \\
1.1(12)\end{array}$ & $\begin{array}{l}84.3 \pm \\
2.1(12)\end{array}$ & $\begin{array}{l}79.4 \pm \\
5.9(6)\end{array}$ & $\begin{array}{l}66.8 \pm \\
5.5(6)\end{array}$ \\
\hline
\end{tabular}

${ }^{\mathrm{a}} p<0.01$ in comparison with vehicle-treated controls; $n$ given in parentheses

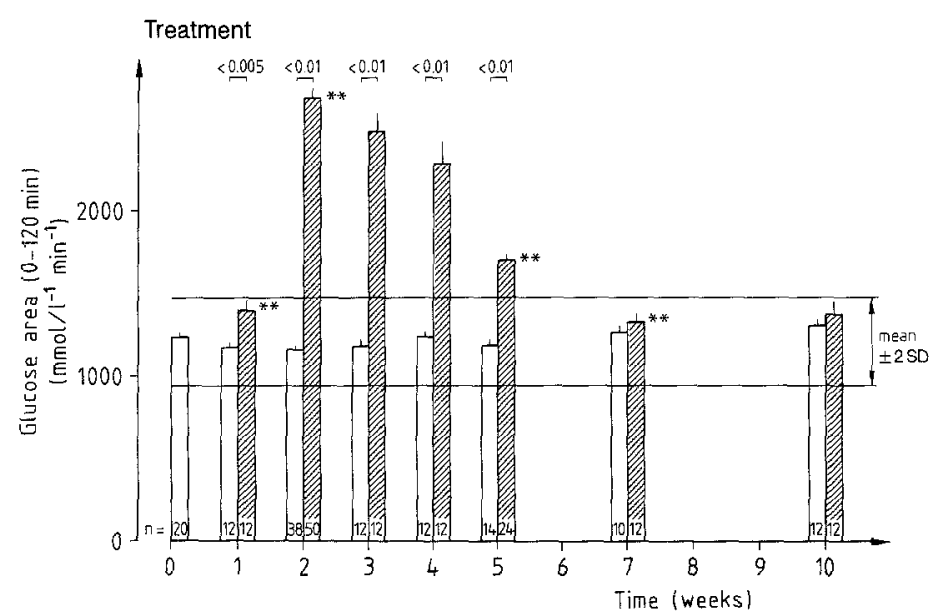

Fig. 1. Glucose tolerance (calculated as glucose area $0-120 \mathrm{~min}$ ) of vehicle-treated $(\square)$ or Cyclosporin A-treated (四) animals. Normal values (mean $\pm 2 \mathrm{SD}$ ) obtained from 70 untreated male WOK-rats are also given. ${ }^{*} p<0.01$ in comparison to the former time investigated

closporin A-RIA kit supplied by Sandoz Ltd. (Basel, Switzerland). The Cyclosporin $A$ recovery measured in the presence of pancreas $(158 \pm 2 \mathrm{mg})$, kidney $(106 \pm 5 \mathrm{mg})$ or liver $(92 \pm 7 \mathrm{mg})$ was, at $85.2 \pm$ $5.3 \%, 86.0 \pm 5.3 \%, 84.0 \pm 6.9 \%(n=5)$, identical in the tissues investigated. The intraassay variation coefficient for Cyclosporin A determination was $3.3 \%$, the interassay coefficient was $4.2 \%$ at medium concentrations.

For morphometric investigations the Bouin-fixed and paraffinembedded pancreas was cut into $7 \mu \mathrm{m}$ serial sections. The relative islet volume was measured on haematoxylin-eosin stained sections, the relative B-cell volume on immunostained sections using guinea pig anti-insulin serum and fluorescein-isothiocyanat-labelled goat-antiguinea pig immunoglobulin (Staatliches Institut für Immunpräparate und Nährmedien, Berlin, GDR) by point sampling [14,15].

\section{Investigations of pancreatic islets}

The islets were prepared using a laboratory modification [16] of the collagenase technique [17]. Groups of 30 islets were preincubated at $37{ }^{\circ} \mathrm{C}$ for $30 \mathrm{~min}$ in Krebs-Ringer bicarbonate buffer supplemented with $20 \mathrm{mmol} / 1 \mathrm{Hepes}, 1 \mathrm{mg} / \mathrm{ml}$ bovine serum albumin and $5 \mathrm{mmol} / \mathrm{l}$ glucose. To investigate insulin secretion, groups of 5 similar-sized pancreatic islets were incubated in $0.5 \mathrm{ml}$ of identical buffer with 1.5 , $5.0,10.0$ or $15.0 \mathrm{mmol} / 1$ glucose or $10.0 \mathrm{mmol} / 1$ glucose plus $0.1 \mathrm{mmol} / \mathrm{l}$ isobutylmethylxanthine (IBMX) for $180 \mathrm{~min}$ at $37^{\circ} \mathrm{C}$ in an atmosphere of $95 \% \mathrm{O}_{2}$ [16]. The islet insulin content was measured in 3 samples of each islet preparation using freshly isolated tissue after ultrasonic homogenization [16]. The mean value was used for statistical evaluation.

To measure thymidin incorporation into pancreatic islet DNA, the islets either obtained from vehicle or CS-A treated rats were cultured in $2.0 \mathrm{ml}$ tissue culture medium 199 (TCM 199, Serva, Feinbiochemica, Heidelberg, FRG) in the presence of $5 \mathrm{mmol} / 1$ glucose, $10 \%$ heatinactivated autologous serum and $148 \mathrm{kBq} / \mathrm{ml}$ (methyl- ${ }^{3} \mathrm{H}$ )-thymidine (UVVR, Prag, CSSR, specific activity $96 \mathrm{~Bq} / \mathrm{mol}$ ) for $16 \mathrm{~h}$ at $37^{\circ} \mathrm{C}$ in a humidified atmosphere of $5 \% \mathrm{CO}_{2}$ and $95 \%$ air [18]. The sonicated tissue was used to determine the DNA-content by fluorometry $[18,19]$ and the radioactivity of TCA-precipitated material in a liquid scintillation counter [18].

\section{Statistical analysis}

The results are given as mean value \pm SEM of $\mathbf{n}$ samples investigated at each time. Statistical analysis was performed using Student's t-test. Because the vehicle treatment of animals did not influence the parameters measured, the results were combined and used as controls in the majority of parameters. The results obtained in the controls are within one standard deviation of untreated Wistar rats.

Glucose tolerance was also calculated as area from $0 \mathrm{~min}$ till $120 \mathrm{~min}$ of test period.

When calculating the DNA synthesis from each animal, two longterm islet incubations were measured. The mean value of the islets obtained from Cyclosporin A-treated rats were given as percent of the mean value determined with islets obtained from a vehicle-treated sibling (100\%).

\section{Results}

Compared with vehicle-treated rats, the Cyclosporin Atreated animals showed enhanced plasma glucose (Table 1) after the treatment period which was still within the normal distribution of the WOK strain (mean \pm 
2 SD, 4.11-9.45 mmol/l, $n=984)$. Eight weeks after withdrawal the glucose concentration differed between the groups investigated, although not significantly. As Table 1 also demonstrates, the selected form of Cyclosporin A treatment did not yet alter the creatinine concentration; it did, however, temporarily increase the bilirubin concentrations. The Cyclosporin A-treated rats are characterized by a missing weight gain during the treatment period (Table 1). After withdrawal, however, the body weight gain of treated animals was not significantly different from that observed in vehicle-treated animals (Table 1).

Glucose tolerance was already impaired within 1 week of treatment (Fig. 1), and the impairment was further deteriorated at the end of treatment period. A

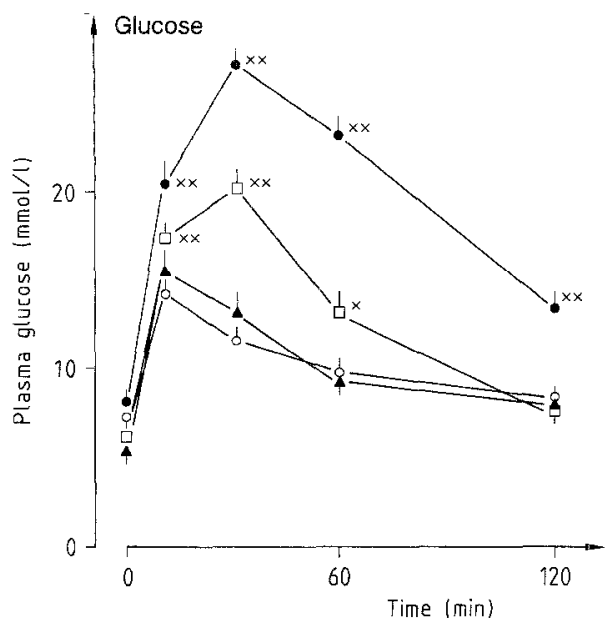

Fig. 2. Glucose tolerance of untreated rats $\left(\mathrm{O}_{-}-\mathrm{O} ; n=20\right)$; of rats after 2 weeks treatment with Cyclosporin $\mathrm{A}(\longrightarrow, n=50)$; and of rats 3 weeks ( $\square-\square ; n=24$ ) and 8 weeks $(\boldsymbol{\Lambda}-\boldsymbol{\Lambda} ; n=12$ ) after drug withdrawal are given. ${ }^{* *} p<0.01,{ }^{*} p<0.05$ in comparison to untreated animals significant improvement in glucose tolerance could not be observed until 3 weeks, and a normalization within 5 weeks after withdrawal of Cyclosporin A (Fig. 1). At that time the altered kinetic of glucose tolerance (peak value changed to $30 \mathrm{~min}, 120 \mathrm{~min}$ value still enhanced) had also been normalized (Fig. 2), despite still measurable Cyclosporin A serum concentrations (Table 3). The pancreatic insulin content was not altered by the vehicle treatment, as demonstrated in Figure 3. Cyclosporin Atreatment resulted in a marked reduction of pancreatic insulin content (Fig. 3), which increased after withdrawal of Cyclosporin A and which was not yet normalized 8 weeks after withdrawal (Fig. 3). The pancreatic glucagon content was not significantly altered by Cyclosporin A (Table 2). The B-cell density was significantly reduced $(\mathrm{p}<0.01)$ after Cyclosporin $A$ treatment accompanied by a diminished islet density and an unchanged non-B cell density (Table 2). Three weeks after withdrawal we observed a further significant decrease of B-cell density, which had been completely normalized, similar to the islet density, 8 weeks after withdrawal.

The insulin content of isolated pancreatic islets was reduced after Cyclosporin $A$ treatment and enhanced after withdrawal (Table 2). The insulin secretion in response to glucose and/or IBMX was markedly diminished when investigating islets prepared from Cyclosporin A-treated rats (Fig. 4). In addition, 5 weeks and 8 weeks after withdrawal of Cyclosporin A, when the pancreas tissue Cyclosporin A concentration was still measurable (Table 3 ), the hormone release was reduced in vitro at least in response to glucose (Fig. 4), whereas the insulin secretion in the presence of IBMX had been normalized (Table 2).

The DNA synthesis of pancreatic islets obtained from Cyclosporin A-treated animals was reduced to

Table 2. Characterization of endocrine pancreas before, during and after Cyclosporin A treatment.

\begin{tabular}{|c|c|c|c|c|c|c|c|c|c|c|}
\hline Parameter & Unit & Vehicle-treated & \multicolumn{2}{|c|}{ Cyclosporin A-treated } & \multicolumn{6}{|c|}{ Weeks after withdrawal } \\
\hline $\begin{array}{l}\text { Pancreatic } \\
\text { glucagon }\end{array}$ & $\mathrm{fmol} / \mathrm{mg}$ & $\begin{array}{c}1714 \pm 114 \\
(18)\end{array}$ & $\begin{array}{c}1275 \pm 119 \\
(9)\end{array}$ & NS & $\begin{array}{c}1330 \pm 242 \\
(6)\end{array}$ & NS & - & - & $\begin{array}{c}1754 \pm 118 \\
(8)\end{array}$ & NS \\
\hline $\begin{array}{l}\text { Islet } \\
\text { idensity }\end{array}$ & $\%$ & $\begin{array}{l}0.98 \pm 0.07 \\
\quad(25)\end{array}$ & $\begin{array}{l}0.61 \pm 0.04 \\
\quad(22)\end{array}$ & $<0.01$ & $\begin{array}{c}0.64 \pm 0.07^{\mathrm{a}} \\
(12)\end{array}$ & NS & $\begin{array}{l}0.76 \pm 0.12 \\
\quad(8)\end{array}$ & NS & $\begin{array}{l}0.90 \pm 0.12 \\
(8)\end{array}$ & NS \\
\hline $\begin{array}{l}\text { Non-B-cell } \\
\text { density }\end{array}$ & $\%$ & $\begin{array}{l}0.23 \pm 0.06 \\
(25)\end{array}$ & $\begin{array}{c}0.23 \pm 0.03 \\
(22)\end{array}$ & NS & $\begin{array}{c}0.36 \pm 0.07 \\
(12)\end{array}$ & NS & $\begin{array}{l}0.37 \pm 0.08 \\
\quad(8)\end{array}$ & NS & $\begin{array}{l}0.22 \pm 0.04 \\
\quad(12)\end{array}$ & NS \\
\hline $\begin{array}{l}\text { Islet in- } \\
\text { sulin } \\
\text { content }\end{array}$ & $\mathrm{pmol} /$ islet & $\begin{array}{c}15.43 \pm 0.92 \\
(38)\end{array}$ & $\begin{array}{l}3.37 \pm 0.30 \\
\quad(22)\end{array}$ & $<0.01$ & $\begin{array}{c}7.99 \pm 0.66^{\mathrm{b}} \\
(12)\end{array}$ & $<0.01$ & $\begin{array}{c}14.50 \pm 1.07 \\
(8)\end{array}$ & $<0.01$ & $\begin{array}{c}10.93 \pm 0.32^{b} \\
(12)\end{array}$ & $<0.05$ \\
\hline
\end{tabular}

${ }^{\mathrm{a}} p<0.05 ;{ }^{\mathrm{b}} p<0.01$ in comparison to vehicle-treated animals; $n$ given in parentheses 
Table 3. Serum and tissue concentration of Cyclosporin A during and after treatment

\begin{tabular}{|c|c|c|c|c|c|}
\hline $\begin{array}{l}\text { Time } \\
\text { (days) }\end{array}$ & $\begin{array}{l}\text { After withdrawal } \\
\text { (days) }\end{array}$ & $\begin{array}{l}\text { Serum } \\
\mu \mathrm{g} / \mathrm{ml}\end{array}$ & $\begin{array}{l}\text { Pancreas } \\
\mu \mathrm{g} / \mathrm{g}\end{array}$ & $\begin{array}{l}\text { Kidney } \\
\mu \mathrm{g} / \mathrm{g}\end{array}$ & $\begin{array}{l}\text { Liver } \\
\mu \mathrm{g} / \mathrm{g}\end{array}$ \\
\hline 7 & & $\begin{array}{c}1.63 \pm 0.23 \\
(9)\end{array}$ & - & - & - \\
\hline 14 & & $\begin{array}{c}5.15 \pm 0.66^{\mathrm{a}} \\
(9)\end{array}$ & $\begin{array}{c}30.52 \pm 8.94 \\
(9)\end{array}$ & $\begin{array}{c}42.32 \pm 6.96 \\
(9)\end{array}$ & $\begin{array}{c}23.26 \pm 5.95 \\
(9)\end{array}$ \\
\hline 28 & (14) & $\begin{array}{l}1.38 \pm 0.13^{\mathrm{a}} \\
\quad(12)\end{array}$ & - & - & - \\
\hline 35 & (21) & $\begin{array}{l}0.12 \pm 0.03^{\mathrm{a}} \\
\quad(12)\end{array}$ & $\begin{array}{c}13.36 \pm 2.58^{\mathrm{a}} \\
(6)\end{array}$ & $\begin{array}{c}17.45 \pm 6.47^{\mathrm{a}} \\
(6)\end{array}$ & $\begin{array}{c}16.81 \pm 0.64^{\mathrm{a}} \\
(6)\end{array}$ \\
\hline 70 & (56) & $\begin{array}{l}0.01 \pm 0.01^{\mathrm{a}} \\
\quad(6)\end{array}$ & $\begin{array}{l}1.83 \pm 0.81^{\mathrm{a}} \\
\quad(6)\end{array}$ & $\begin{array}{l}1.04 \pm 0.79^{\mathrm{a}} \\
\quad(6)\end{array}$ & $\begin{array}{l}0.72 \pm 0.27^{\mathrm{a}} \\
\quad(6)\end{array}$ \\
\hline
\end{tabular}

${ }^{\mathrm{a}} p<0.01$ in comparison to the earlier time investigated; $n$ given in parentheses

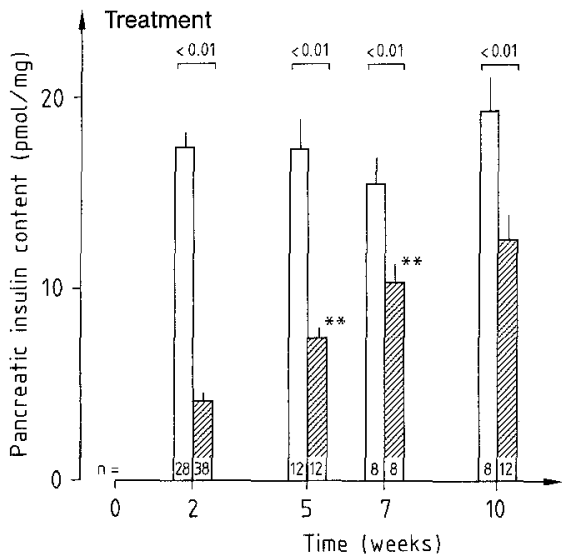

Fig. 3. Pancreatic insulin content of vehicle-treated $(\square)$ and Cyclosporin A-treated (ख) animals. ${ }^{*} p<0.01 ; * p<0.05$ in comparison to the former time investigated

$50 \%$ of that measured in islets obtained from vehicletreated controls (Fig. 5). Three weeks after withdrawal we observed a compensatory enhancement of DNA synthesis; later the DNA synthesis was identical to the controls (Fig. 5).

The serum concentrations of Cyclosporin A rose significantly during the treatment and decreased continuously after withdrawal (Table 3). Similar results were observed by measuring the tissue concentrations of pancreas, liver and kidney (Table 3). The drug was markedly accumulated in the tissue investigated (4.5-8.2-fold) and the decrease of tissue content was much slower than in serum. Whereas 3 weeks after withdrawal the serum contained $2.3 \%$ of the concentration measured at the end of the treatment period, the tissue content varied from $44.2 \%$ (kidney) to $72.8 \%$ (liver).

We could not observe a favoured tissue for Cyclosporin $\mathrm{A}$ accumulation. It was, however, of note that 8 weeks after withdrawal the tissue concentrations were still around $1000 \mathrm{ng} / \mathrm{g}$ wet weight (Table 3 ).



Fig.4. Glucose-stimulated insulin secretion of pancreatic islets, isolated from vehicle-treated controls $(\mathrm{O}, n=21) ; 2$ weeks with Cyclosporin A-treated animals $(\bigcirc n=9)$; and 3 weeks $(\Delta-\Delta$; $n=6$ ) or 8 weeks ( $\square \longrightarrow \square ; n=6$ ) after drug withdrawal. ${ }^{* *} p<0.01$ in comparison to controls; ${ }^{\circ} p<0.01$ in comparison to 2 week-treated animals



Fig. 5. DNA synthesis of isolated pancreatic islets. The mean value \pm SEM of 8-16 experiments is given. The incorporation of $672 \pm$ $25 \mathrm{~Bq}$ thymidin/ $\mu \mathrm{g}$ islet DNA $(n=54)$ represents $100 \%$. ** $p<0.01$ in comparison to the former time investigated 


\section{Discussion}

Cyclosporin A is now widely used in clinical transplantation [1]. The drug has been suggested for use in treatment of autoimmune diseases such as Type 1 diabetes [5-7], despite well known side effects on various parenchymal organs, including the pancreatic B cells [2-4]. In cases of segmental pancreas transplantation, Gunnarsson et al. [20] observed a deterioration of glucose tolerance in Cyclosporin A-treated recipients. The findings to Sutherland et al. [21] suggest that Cyclosporin A may adversely affect the grafted endocrine pancreas. Since Cyclosporin $\mathrm{A}$ is now also used in trials to interrupt the immunological destruction of pancreatic $B$ cells $[6,7]$, it seems important to evaluate any side effects of the drug on endocrine $\mathrm{B}$ cells in more detail.

Recently it has been reported that a Cyclosporin A dose toxic to liver and kidney also destroyed pancreatic $B$ cells in normal Wistar rats $[2,4]$ resulted in glucose intolerance, hyperglycaemia, hypoinsulinaemia, and marked reductions of both relative B-cell volumes and pancreatic insulin contents.

In this study, we have confirmed the acute toxic action of Cyclosporin A on pancreatic B cells, and have investigated if and to what extent the pancreatic $B$ cells are able to recover from these alterations. Cyclosporin A dose and timing of the experiments were chosen in order to precipitate glucose intolerance in vivo without inducing overt diabetes or toxic effects on liver and kidney.

Within 5 weeks after withdrawal of Cyclosporin A, the glucose intolerance was completly reversible, indicating that the recovery of B-cell function is a time-consuming process. We have never observed such a reversibility of glucose intolerance after the application of subthreshold beta-cytotoxic diabetogenic agents [22], suggesting basically different mechanisms of B-cell damage induced by Cyclosporin $\mathrm{A}$ and by streptozotocin. Cyclosporin A-induced glucose intolerance is either caused by a reduced capacity of pancreatic B cells to store insulin, indicated by the markedly decreased pancreatic insulin content, or provoked by an interference with the insulin-secretory machinery indicated by the small secretory response of pancreatic islets in vitro (Fig.4, Table 2). Such effects could still be observed 3 weeks after withdrawal, although the B cells had been already regranulated (Table 2). Besides these functional alterations, Cyclosporin A also induced a decrease of the B-cell amount, as demonstrated by the reduction of relative islet volume due to a loss of insulin-positive cells (Table 2). The demonstration of a further significant decrease of B-cell density 3 weeks after Cyclosporin $\mathrm{A}$ withdrawal (i.e. at a time when the islet insulin content had already been enhanced), also ruled out that the morphometric results obtained can only be ascribed to a marked B-cell degranulation below the detection limit of the method used (i.e. $1.0 \mathrm{pmol} / \mathrm{mg}$ pancreatic wet weight [15]). In addition to the toxic destruction of pancreatic $B$ cells by Cyclosporin $A$, as also documented by electron microscopy [4], we suggest that a decrease of replicatory activity (Fig. 5) [23] may contribute to the diminution of B-cell amount. During the "regeneration period", finally leading to a complete recovery of islet and B-cell density, a temporary stimulation of islet replication became apparent. It can only be speculated if such a replication process was the basis for the complete recovery of B-cell density documented 8 weeks after withdrawal of Cyclosporin A.

It was interesting that the stepwise improvement of the various parameters of B-cell function and morphology after Cyclosporin A withdrawal were observed despite prevailing serum and tissue concentrations of $\mathrm{Cy}$ closporin A, suggesting that a Cyclosporin A threshold and/or accumulation may have to be reached before the pancreatic $B$ cells are toxically damaged.

Acknowledgements. The study is part of the "Hauptforschungsrichtung - Diabetes Mellitus und Fettstoffwechselstörungen" supported by the Ministry of Health of the German Democratic Republic. We wish to thank Dr. E. Wiskott (Sandoz AG, Basel, Switzerland) for supporting us with Cyclosporin A and the RIA kits for Cyclosporin A determination. The expert technical help of Ms. M. Henkel, Ms. G. Strauch, and Ms K.Gumm is also gratefully acknowledged. We also thank Ms P. Pohl for typing the manuscript and Mr. J. Fanning for linguistic corrections.

\section{References}

1. Weil C (1984) Cyclosporin A: Review of results in organ and bone-marrow transplantation in man. Med Res Rev 4: 221-265

2. Hahn HJ, Laube F, Lucke S, Klöting I, Kohnert KD, Warzock R (1986) Toxic effects of Cyclosporin A on the endocrine pancreas of Wistar rats. Transplantation 41: 44-47

3. Yale JF, Roy RD, Grose M, Seemayer TA, Murphy GR, Marliss EB (1985) Effects of Cyclosporine on glucose tolerance in the rat. Diabetes 34: 1309-1313

4. Helmchen U, Schmidt EW, Siegel EG, Creutzfeldt W (1984) Morphological and functional changes of pancreatic B cells in Cyclosporin A-treated rats. Diabetologia 27: 416-418

5. Stiller CR, Dupré J, Gent M, Jenner MR, Keown PA, Laupacis A, Martell R, Rodger NW, v Graffenried B, Wolfe BMJ (1984) Effects of Cyclosporine Immunosuppression in insulin-dependent diabetes mellitus of recent onset. Science 223: 1362-1367

6. Assan R, Debray-Sachs M, Laborie C, Chatenoud L, Feutren G, Quiniou-Debrie MC, Thomas G, Bach JF (1985) Metabolic and immunological effects of Cyclosporin in recently diagnosed type 1 diabetes mellitus. The Lancet 12:67-71

7. Nerup J, Bendtzen K, Mandrup-Poulsen T (1985) A role for Cyclosporin $\mathrm{A}$ in the treatment of insulin-dependent diabetes mellitus? Diab Med 2: 441-446

8. Hellerström C (1984) The life story of the pancreatic $\beta$-cell. Diabetologia $28: 172-175$

9. Logothetopoulos J, Valiquette N, Madura E, Cvet D (1984) The onset and progression of pancreatic insulitis in the overt spontaneously diabetic, young adult BB rat studied by pancreatic biopsy. Diabetes 33: 33-36

10. 2. Arzneibuch der DDR: Diagnostische Laboratoriumsmethoden 1983, Berlin: Akademie-Verlag 1983

11. Ziegler B, Hahn HJ, Ziegler M (1985) Insulin recovery in pancreas and host organs of islet grafts. Exp Clin Endocrinol 85: 53-60

12. Gottschling HD, Ziegler M, Keilacker H, Konradt M (1977) Ultramikro-Radioimmunoassay für Insulin unter Verwendung kom- 
merzieller Radioimmun-Reagenzien. Radiobiol Radiother 18: 225-229

13. Ziegler M, Michael R, Stein HH, Klatt D (1974) Radioimmunoassay von Pankreasglukagon isolierter Langerhans'scher Ratteninseln nach dem Prinzip der Rücktitration. Radiobiol Radiother 15: 79-84

14. Weibel ER (1969) Stereological principles for morphometry in electron microscopic cytology. Int Rev Cytol 26: 235-302

15. Lucke S, Ziegler B, Diaz-Alonso JM, Hahn HJ (1985) Eignung spezifischer Färbemethoden für die Bestimmung des $\beta$-Zellvolumens im Rattenpankreas mit normalem und reduziertem Insulingehalt. Acta Histochem 77: 107-116

16. Hahn HJ (1978) Die isolierte Langerhans'sche Insel, ein Modell zur Untersuchung der Insulinsekretion in vitro. Endokrinologie 71: $308-324$

17. Moskalewski $S$ (1965) Isolation and culture of the islets of Langerhans of the guinea pig. Gen \& Comp Endocrinol 5: 342-353

18. Ziegler B, Kohnert KD, Noack S, Hahn HJ (1982) Effects of 3-isobutyl-1-methylxanthine on secretory response, cAMP accumulation and DNA synthesis of islets from postnatal and adult Wistar rats. Acta Biol Med Germ 41: 1171-1177

19. Kissane JM, Robins E (1958) The fluorometric measurement of DNA in animal tissues with special references to the central nervous system. J Biol Chem 233: 184
20. Gunnarsson R, Klintmalm G, Tydén G, Wilczek H, Östman J, Groth GG (1984) Deterioration in glucose metabolism in pancreatic transplant recipients after conversion from azathioprine to cyclosporine. Transplant Proc 16: 709-712

21. Sutherland DER, Goetz FC, Kendall DM, Najarian JS (1985) Effect of donor source, technique, immunosuppression, and presence or absence of end-stage diabetic nephropathy on outcome in pancreas transplant recipients. Transpl Proc 17: 325-330

22. Ziegler B, Lucke S, Besch W, Hahn HJ (1985) Pregnancy associated changes in the endocrine pancreas of normoglycaemic streptozotocin-treated Wistar rats. Diabetologia 28: 172-175

23. Andersson A, Borg H, Hallberg A, Hellerström C, Sandler S, Schnell A (1984) Long-term effects of Cyclosporin A on cultured mouse pancreatic islets. Diabetologia 27:66-69

Received: 4 September 1985

and in revised form: 8 June 1986

Dr. H.-J.Hahn

Zentral Institut für Diabetes

"Gerhardt Katsch"

DDR-2201 Karlsburg

GDR 